Journal of Environmental Science and Public Health

doi: 10.26502/JESPH.007

Volume 1, Issue 2

Research Article

\title{
Generation of Bio-Electricity from Sewage Sludge Using Single Chamber Microbial Fuel Cell
}

\author{
Kumar Sonu* \\ Department of Mechanical Engineering, Anand International College of Engineering, Jaipur, Rajasthan, India \\ *Corresponding Author: Kumar Sonu, Department of Mechanical Engineering, Anand International College of \\ Engineering, Near Kanota, Agra Road, Jaipur - 303012, Rajasthan, India, Tel: 01429234 994; E-mail: \\ kumar_sonuasg@yahoo.com
}

Received: 03 July 2017; Accepted: 20 July 2017; Published: 02 August 2017

\begin{abstract}
A Single Chamber Microbial Fuel Cell (MFC) has been fabricated to generate electricity from the sludge of the sewage treatment plant at Anand International College of Engineering, Jaipur, at two different ambient temperature range of $25 \pm 4^{\circ} \mathrm{C}$ and $32 \pm 4^{\circ} \mathrm{C}$ under aerobic condition. The maximum voltage obtained was about $2890 \mathrm{mV}$ after 80 (hrs.) at temperature range of $25 \pm 4^{\circ} \mathrm{C}$, with the surface power density of $1108.29 \mathrm{~mW} / \mathrm{m}^{2}$. When the ambient temperature was $32 \pm 4^{\circ} \mathrm{C}$, the maximum voltage obtained was $1652 \mathrm{mV}$ after 40 (hrs.) surface power density reduced to $865.57 \mathrm{~mW} / \mathrm{m}^{2}$. While changing the amount of substrate for certain area of the electrode at $25 \pm 4^{\circ} \mathrm{C}$ range it showed that the electricity generation decreased with the available substrate and it also shortens the time to peak voltage. On the other way when the ambient temperature increased to $32 \pm 4^{\circ} \mathrm{C}$, the maximum potential energy generated is less than the previous temperature for the same substrate per unit area of the electrode and also the time to peak voltage decreases to $40 \mathrm{hrs}$. At the end of the 152 (hrs.), the maximum COD reduction for the sewage sludge was $30 \%$ for $32 \pm 4^{\circ} \mathrm{C}$. When comparing with other single chambers MFC, the present model is generating more electricity that any MFC using sewage sludge as substrate except platinum electrode, which is much costlier that electrode used in the present study.
\end{abstract}

Keywords: Graphite electrode; Microbial fuel cell; Sewage sludge; Used dry cell

\section{Introduction}

The microbial fuel cell is a device which generates electricity by the metabolic activities of the microbes. Microorganisms transfer the electrons obtained from the metabolism of organic matters in the anode and thereby to the 
cathode through an external circuit, hence generate electricity $[1,2]$. Though a century old technique, which was initially recognized for treatment of wastewater, MFC is gaining its interest for the generation of electricity, bio-hydrogen and also used as biosensor [3, 4]. Any biodegradable organic ranging from pure compounds such as glycerol, acetate, starch, glucose, cysteine, and ethanol [3,5] to complex mixtures of organic matter such as wastewater [6], cow dung [2], and kitchen waste [6] are the ideal candidates of sustainable energy source for MFC. The performance of microbial fuel cell depends upon the types of electrode materials, microbe \& substrate and its concentration, $\mathrm{pH}$, temperature and ionic strength.

The various types of the electrode that can be used in the construction of the microbial fuel cell are graphite; graphite felt, Platinum (Pt.), Pt. black, carbon paper, reticulated vitreous carbon (RVS). The design of MFC may be 1. Two compartment MFC systems consisting of an anodic chamber and catholic chamber separated by proton exchange membrane (PEM) or sometime salt bridge to allowing the proton to move across the blocking the diffusion of oxygen into the anode [3]. 2. Single-compartment MFC systems consisting of the single anodic chamber without the any aerated catholic chamber [3]. The anode chamber is coupled to a porous air-cathode exposing directly to the air.

The Single-compartment MFC systems is cheaper than that of two compartments MFC. The traditional dual chamber which is bulky due to two separate anode and cathode chambers, the single chamber containing single anode chamber omitting the cathode chamber where the cathode is placed as membrane and exposed to air is much more efficient and cost effective than dual chamber MFC.

Table 1 shows the performance of single chamber microbial fuel cell for the different substrate on the basis of maximum power density. The maximum surface power density of $6000 \mathrm{~mW} / \mathrm{m}^{2}$ using platinum electrode modified polyanilineco and sewage sludge was found from the literature available [7]. When the sewage sludge used with graphite electrode 152 $\mathrm{mW} / \mathrm{m}^{2}$ maximum surface power density could be achieved [7].

\begin{tabular}{|c|c|c|c|c|}
\hline $\begin{array}{l}\text { Sl. } \\
\text { No. }\end{array}$ & Industry/Substrate & System configuration & $\begin{array}{l}\text { Maximum surface } \\
\text { power density }\end{array}$ & Refs. \\
\hline \multirow{2}{*}{1} & \multirow{2}{*}{ Sewage sludge } & Electrode: Single chamber (graphite electrode) & $152 \mathrm{~mW} / \mathrm{m}^{2}$ & [7] \\
\hline & & $\begin{array}{l}\text { Single chamber (Platinum and } \\
\text { polyanilineco-modified) }\end{array}$ & $6000 \mathrm{~mW} / \mathrm{m}^{2}$ & [7] \\
\hline 2 & $\begin{array}{l}\text { Glycerol -waste } \\
\text { water }\end{array}$ & $\begin{array}{l}\text { Single-chamber } \\
\text { Temperature }\left({ }^{\circ} \mathrm{C}\right): 30^{\circ} \mathrm{C} \\
\text { pH: } 7\end{array}$ & $600 \mathrm{~mW} / \mathrm{m}^{2}$ & [8] \\
\hline 3 & $\begin{array}{l}\text { Meat packing } \\
\text { wastewater }\end{array}$ & $\begin{array}{l}\text { One-chamber, Carbon paper loaded with0. } 35 \mathrm{mg} \\
\text { platinum } / \mathrm{cm} 2 \\
\text { Temperature }\left({ }^{\circ} \mathrm{C}\right): \mathrm{NA} \\
\text { pH: NA }\end{array}$ & $80 \pm 1 \mathrm{~mW} / \mathrm{m}^{2}$ & [9] \\
\hline
\end{tabular}




\begin{tabular}{|c|c|c|c|c|}
\hline 4 & $\begin{array}{l}\text { Starch processing } \\
\text { wastewater }\end{array}$ & $\begin{array}{l}\text { One-chamber air-cathode MFC with carbon paper } \\
\text { anode }(25 \mathrm{~cm} 2) \\
\text { Temperature }\left({ }^{\circ} \mathrm{C}\right): 30 \pm 1{ }^{\circ} \mathrm{C} \\
\text { pH: } 7.1 \pm 0.1\end{array}$ & $239.4 \mathrm{~mW} / \mathrm{m}^{2}$ & [10] \\
\hline 5 & Swine wastewater & $\begin{array}{l}\text { Single-chambered air cathode } \\
\text { Temperature }\left({ }^{\circ} \mathrm{C}\right): 30^{\circ} \mathrm{C} \\
\text { pH: NA. }\end{array}$ & $261 \mathrm{~mW} / \mathrm{m}^{2}$ & [11] \\
\hline 6 & Brewery wastewater & $\begin{array}{l}\text { One-chamber air-cathode MFC with non-wet } \\
\text { proofed carbon cloth as anode }(7 \mathrm{~cm} 2) \text { and wet } \\
\text { proofed carbon cloth containing Pt as cathode } \\
\text { Temperature }\left({ }^{\circ} \mathrm{C}\right): 30^{\circ} \mathrm{C} \\
\text { pH: } 6.5 \pm 0.2\end{array}$ & $205 \mathrm{~mW} / \mathrm{m}^{2}$ & [12] \\
\hline 7 & $\begin{array}{l}\text { Paper recycling } \\
\text { wastewater }\end{array}$ & $\begin{array}{l}\text { One-chamber MFC with graphite fiber-brush anode } \\
(5418 \mathrm{~m} 2 / \mathrm{m} 3 \text { brush volume) } \\
\text { Temperature }\left({ }^{\circ} \mathrm{C}\right): 22-26^{\circ} \mathrm{C} \text { (Room Temperature) } \\
\text { pH: } 7\end{array}$ & $501 \pm 20 \mathrm{~mW} / \mathrm{m}^{2}$ & [13] \\
\hline
\end{tabular}

Table 1: Performance of single chamber MFC under different types of industrial waste.

In conventional single chamber MFC the anode and cathode are separated by a membrane or sometime cathode is directly exposed to air. In both the cases, anode and cathode are completely different material in design and composition. In our present studies, we are using single chamber MFC where the carbon rod extracted from the used dry cell is used as anode and copper as a cathode. The substrate used here is domestic sewage sludge.

\section{Materials and Methodology}

\subsection{Collection and preservation of sample}

The sewage sludge is collected from the waste water treatment plant at Anand International College of Engineering, Jaipur. The sludge was preserved at $4^{\circ} \mathrm{C}$ after collection and before using in MFC [12]. The physiochemical characteristics of the sludge used in MFC are shown in the Table 2.

\begin{tabular}{|c|l|c|}
\hline Sl.No & \multicolumn{1}{|c|}{ Parameters } & Values \\
\hline 1 & COD & $80000 \mathrm{mg} / \mathrm{l}$ \\
\hline 2 & \% of Total Solid & 17.2 \\
\hline 3 & \% of Volatile Solid & 11.6 \\
\hline 5 & Colour & Grey \\
\hline 6 & $\mathrm{pH}$ & 5.3 \\
\hline
\end{tabular}

Table 2: Physiochemical properties of sewage sludge used in MFC. 


\subsection{Design}

Six numbers of single chamber MFCs having carbon electrode as anode and copper as a cathode connected externally in series with copper wire have been used in this present study. Each electrode is submerged into the sludge and copper cathode is exposed to the atmosphere. Figure 1 shows the experimental setup in details.

The various components in microbial fuel cell are as follow;

2.2.1 Electrode: The carbon electrodes were taken from the used dry cell to absorb electrons from the substrate, before using the electrodes were cleaned with $0.1 \mathrm{M} \mathrm{HCl}$ and stored in deionized water for $12 \mathrm{hr}$. The dimension of the electrode is $10 \mathrm{~mm}$ diameter and $57 \mathrm{~mm}$, respectively having $40 \mathrm{~mm}$ (70\% length) as the anode and $17 \mathrm{~mm}$ as cathode over which the copper wire was bounded acting as the cathode. Hence the surface area of an anode is $1256 \mathrm{~mm}^{2}$.

2.2.2 Copper wires: The copper wires of $0.7 \mathrm{ohms}$ resistance were connected with the electrodes. The external circuit was in series connections.

2.2.3 Calibrated multimeter: To measure the voltage output (Model No.MAS83OL).

2.2.4 pH meter: To measure the $\mathrm{pH}$ of the sewage sludge ( Make: Systronics).

The carbon electrodes were fixed in the containers with the help of the copper wires and are connected in series externally. The collected sewage sludge was mixed uniformly and was poured into the container and allowed the bacteria present in it to grow and start the metabolic activities in aerobic condition (Figure 1).

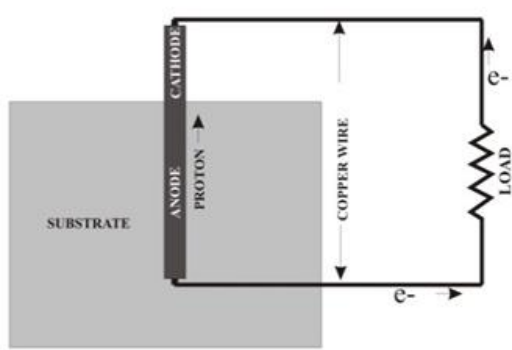

(a)

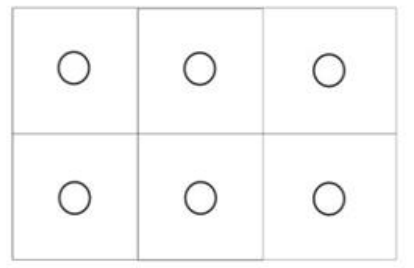

SET I

Amount of sludge $=180 \mathrm{ml} /$ cell COD of the substrate $=14400 \mathrm{mg} /$ cell Ambient temperature $=25 \pm 4^{\circ} \mathrm{C}$

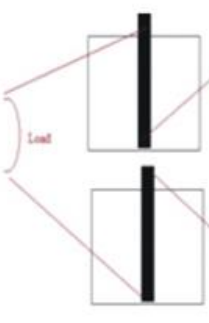

(b)

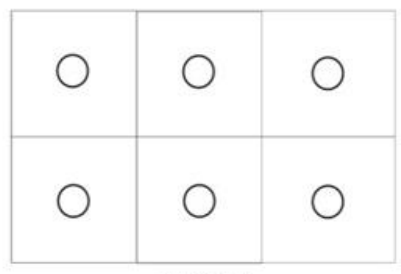

SET II

Amount of sludge $=90 \mathrm{ml} /$ cell COD of the substrate $=7200 \mathrm{mg} /$ cell Ambient temperature $=25 \pm 4^{\circ} \mathrm{C}$

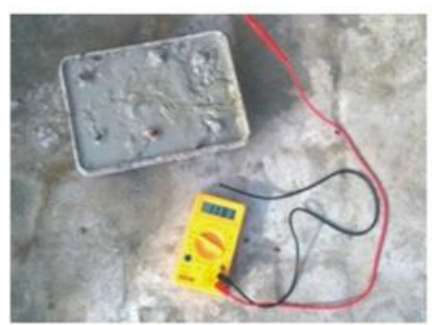

(c)

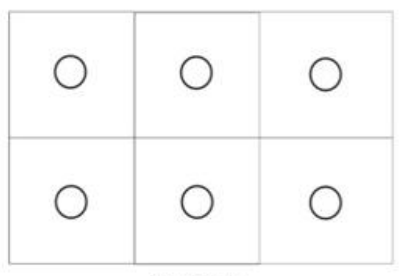

SET III

Amount of sludge $=180 \mathrm{ml} /$ cell COD of the substrate $=14400 \mathrm{mg} /$ cell Ambient temperature $=32 \pm 4^{\circ} \mathrm{C}$

(d)

Figure 1: Single chamber MFC (a) Circuit diagram of the single cell of single chamber single MFC. (b) Schematic representation of the circuit diagram of single chamber MFC in series (c) Photograph of the experimental setup of the combination of the single chamber. (d) Schematic representation of the three different setups of MFC studied. 


\subsection{Performance evaluation criteria}

For all the three sets the voltage output was recorded by the multimeter across the resistor of $1000 \mathrm{ohm}$ at the regular interval of $8 \mathrm{hrs}$ and continuously operated until the energy generation is diminished to zero (least count of the multimeter is $0.01 \mathrm{mV}$ ). The first two sets were operated at the ambient temperature of $25 \pm 4^{\circ} \mathrm{C}$ while the third set is operated at the ambient temperature of $32 \pm 4^{\circ} \mathrm{C}$, which was within 10 days.

The surface power density $\mathrm{P}\left(\mathrm{mW} / \mathrm{m}^{2}\right)$ is calculated as $P=V^{2} /(R \times A \times 1000)$, where $\mathrm{V}(\mathrm{mV})$ is the measured fuel cell voltage, $\mathrm{R}(\mathrm{ohm})$ external resistant and $\mathrm{A}\left(\mathrm{m}^{2}\right)$ projected surface area of the anode, 1000 is needed for maintaining the units.

\section{Result and Discussion}

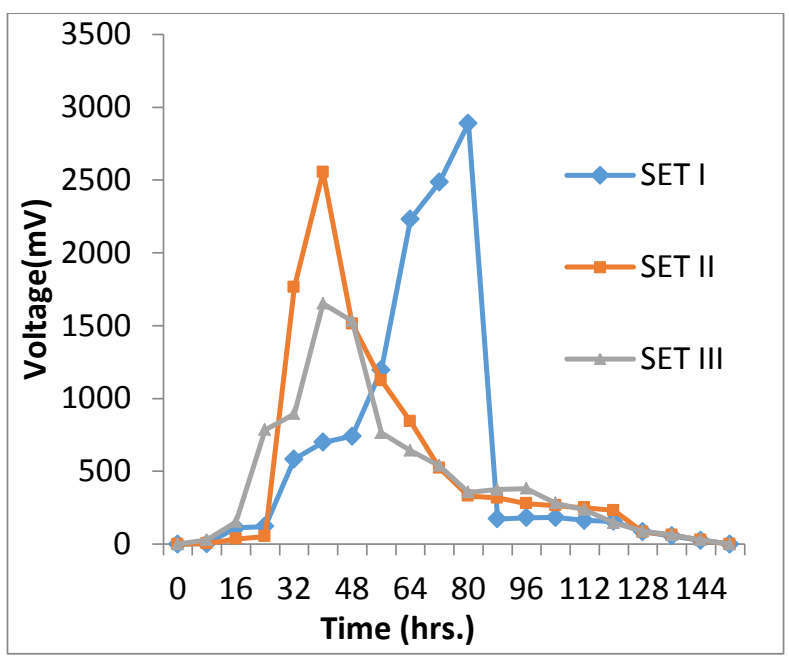

Figure 2: Voltage (mV) vs. Time (hrs.) for all the 3 SETs.

The maximum voltage obtained from the study was about $2890 \mathrm{mV}$ after 80 (hrs.) for the SET Iat ambient temperature of $25 \pm 4^{\circ} \mathrm{C}$. At the same average ambient temperature in SET II , we could able to achieve $2554 \mathrm{mV}$ after 40 (hrs.) where the quantity (hence the amount of available COD) of the sewage sludge is half that of SET I. In SET III though the quality of sewage sludge is same as that of SET I but we could able to achieve only $1652 \mathrm{mV}$ after 40 (hrs.) at an average ambient temperature of $32 \pm 4^{\circ} \mathrm{C}$.

\begin{tabular}{|c|c|c|c|c|c|c|}
\hline \multirow{2}{*}{} & \multicolumn{2}{|c|}{ SET I } & \multicolumn{2}{c|}{ SET II } & \multicolumn{2}{c|}{ SET III } \\
\cline { 2 - 7 } & Initial & Final & Initial & Final & Initial & Final \\
\hline $\mathrm{pH}$ & 5.3 & 4.5 & 5.3 & 4.6 & 5.3 & 6.1 \\
\hline $\begin{array}{c}\mathrm{COD}(\mathrm{mg} / \mathrm{L}) \\
{[\% \text { decrease }]}\end{array}$ & 80000 & 58000 & 80000 & 72000 & 80000 & 56000 \\
{$[27.5 \%]$} & & {$[10 \%]$} & & {$[30 \%]$} \\
\hline
\end{tabular}

Table 3: Change of $\mathrm{pH}$ and COD in three different sets of Microbial Fuel Cell. 
The $\mathrm{pH}$ of the sewage sludge found to decrease from 5.3 to 4.5 in SET I (Table 3). For SET II the pH reduced from 5.3 to 4.6 But in SET III the pH increased from 5.3 to 6.1. At the end of the152 (hrs.), the COD of the sewage sludge for the SET I was $58000 \mathrm{mg} / \mathrm{l}$ (reduction of 27.5\%), In case of SET II the COD was $72000 \mathrm{mg} / \mathrm{l}$ (reduction of $10 \%$ ), finally for the SET III it is $56000 \mathrm{mg} / \mathrm{l}$ (reduction of $30 \%$ ).

Results obtained from the SET III clearly indicate that at elevated temperature the metabolic activities of the microbes reduce and even the $\mathrm{pH}$ of the sewage sludge is increased, thereby reducing the surface power density. But at the same time there is the slight improvement in the COD reduction.

\section{Conclusion}

The present study is a novel and economical (cost of each cell Rs.250/-only) single chamber microbial fuel cell for the generation of electricity. Result found is very encouraging when compared to other single chamber MFC. The highest surface power density found to be $1108.29 \mathrm{~mW} / \mathrm{m}^{2}$ which is more than any other single chamber MFC excluding platinum electrode (Table 1). Both SET I and SET II are experimented at the same ambient temperature and substrate, where SET II is giving less potential energy. This is because the amount of substrate (hence COD) available for anode at SET II is less than SET I. SET I and SET II are designed in such a way that the same amount of surface area of the electrode is exposed to the substrate in both cases. Thus, in SET II reducing the volume of the substrate in half will also decrease in substrate availability per unit area of the electrode to half. The reduced available substrate per unit area of the electrode not only reduced the peak potential energy, but it also shortens the time to peak voltage. SET III which is operated at the elevated ambient temperature $\left(32 \pm 4^{\circ} \mathrm{C}\right)$ gives less peak potential energy than SET I and SET II thus indicating that among the two different range of ambient temperature $25 \pm 4^{\circ} \mathrm{C}$ and $32 \pm 4^{\circ} \mathrm{C}$, the previous one is more promising.

As per the very preliminary study conducted on the presented single chamber, MFC is can be undoubtedly said that the current model is capable of generation of electricity from the domestic sewage sludge economically and effectively.

\section{Acknowledgement}

We are very grateful to Anand International College of Engineering, Jaipur for the financial support to carry out the above project work.

\section{References}

1. Potter MC. Electrical effects accompanying the decomposition of organic compounds. Proc R Soc London Ser B 84 (1911): 260-276.

2. Guang Zhao, Fang Ma, Li Wei, et al. Electricity generation from cattle dung using microbial fuel cell technology during anaerobic acidogenesis and the development of microbial populations. Waste Management 32 (2012): 1651-1658. 
3. Logan BE, Hamelers B, Rozendal R, et al. Microbial Fuel Cells: Methodology and Technology. Environ Sci Technol 40 (2006): 5181-5192.

4. Wang H, Park JD, Ren ZJ. Practical Energy Harvesting for Microbial Fuel Cells: A Review. Environ Sci Technol 49 (2015): 3267-3277.

5. Kim JR, Jung SH, Regan JM et al. Electricity generation and microbial community analysis of alcohol powered microbial fuel cells. Biores Technol 98 (2007): 2568-2577.

6. Das S, Mangwani N. Recent development in microbial fuel cell: a review. Journal of Scientific and Industrial Research. 69 (2010): 727-731.

7. Rahimnejad M, Adhami A, Darvari S, et al. Microbial fuel cell as new technology for bioelectricity generation: A review. Alexandria Engineering Journal 54 (2015): 745-756.

8. Nimji VR, Chen CJ, Chen CC, et al. Glycerol degradation in single-chamber microbial fuel cells. Bioresource Technolog 102 (2010): 2629-2634.

9. Heilmann J, Logan BE. Production of electricity from proteins using a microbial fuel cell. Water Environ Res 78 (2006): 531-537.

10. Liu H, Cheng S A, Logan BE. Production of electricity from acetate or butyrate using a single-chamber microbial fuel cell. Environ Sci Technol 39 (2005): 658-662.

11. Min B, Kim JR, Oh S, et al. Electricity generation from swine wastewater using microbial fuel cells. Water Res 39(2005): 4961-4968.

12. Feng Y, Wang X, Logan BE, et al. Brewery wastewater treatment using air-cathode microbial fuel cells. Appl Microbiol Biotechnol 78 (2008): 873-880.

13. Huang LP, Logan BE. Electricity generation and treatment of paper recycling wastewater using a microbial fuel cell. Appl Microbiol Biotechnol 80 (2008): 349-355.

This article is an open access article distributed under the terms and conditions of the Creative Commons Attribution (CC-BY) license 4.0 